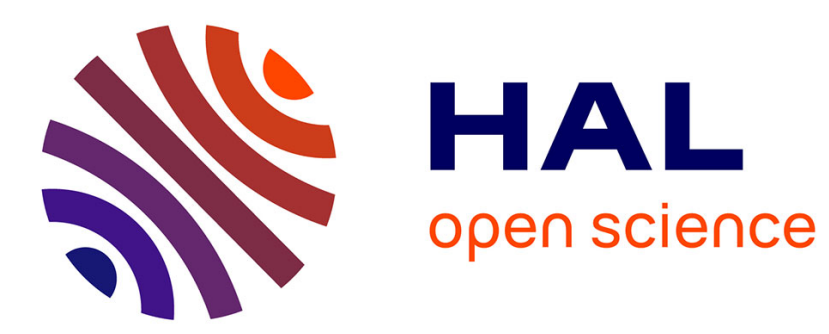

\title{
Crystallization and Preliminary Crystallographic Data for Bovine Antithrombin III
}

J.P. Samama, M. Delarue, L. Mourey, J. Choay, D. Moras

\section{To cite this version:}

J.P. Samama, M. Delarue, L. Mourey, J. Choay, D. Moras. Crystallization and Preliminary Crystallographic Data for Bovine Antithrombin III. Journal of Molecular Biology, 1989, 210 (4), pp.877-879. 10.1016/0022-2836(89)90116-2 . hal-03004885

\section{HAL Id: hal-03004885 \\ https://cnrs.hal.science/hal-03004885}

Submitted on 20 Nov 2020

HAL is a multi-disciplinary open access archive for the deposit and dissemination of scientific research documents, whether they are published or not. The documents may come from teaching and research institutions in France or abroad, or from public or private research centers.
L'archive ouverte pluridisciplinaire HAL, est destinée au dépôt et à la diffusion de documents scientifiques de niveau recherche, publiés ou non, émanant des établissements d'enseignement et de recherche français ou étrangers, des laboratoires publics ou privés. 


\title{
Crystallization and Preliminary Crystallographic Data for Bovine Antithrombin III
}

\begin{abstract}
Crystals of bovine antithrombin III were obtained in the presence of metal ions with ammonium sulphate as precipitating agent. Crystals belong to space group $P 4_{1} 2_{1} 2$ or $P 4_{3} 2_{1} 2$ with cell parameters $a=b=91 \cdot 4 \AA, c=383.1 \AA$; there are two molecules per asymmetric unit. Electrophoresis experiments and amino acid sequence analysis of the N-terminal part of redissolved crystals suggest that the protein molecules are cleaved at the active site.
\end{abstract}

Bovine antithrombin III ( $\left.\Lambda^{\prime} \mathrm{TIII} \dagger\right)$ is a single chain glycoprotein of molecular weight $\mathbf{5 6 , 6 0 0}$ (Kurachi et al., 1976). Abundant in blood serum, antithrombin III inhibits primarily serine proteases of the blood coagulation pathway, such as factors IXa, Xa and XIa (Rosenberg, 1977) and thrombin, which, from consideration of relative rates of inactivation, is thought to be its principal physiological target (Travis \& Salvensen, 1983).

Inhibition of serine proteases was shown to occur through the formation of a $1: 1$ stable complex of enzyme and inhibitor (Damus et al., 1973). The rate of inactivation of thrombin by ATIII is enhanced by four orders of magnitude upon binding of a polysaccharide, heparin (Jordan et al., 1980; Hoylaerts et al., 1984). When this tight complex is dissociated, the bovine ATIII molecule is found to be cleaved at a specific peptide bond: Arg393Ser394 (Jörnvall et al., 1979). This cleaved molecule $\left(\mathrm{AT}_{\mathrm{M}}\right)$, made of two fragments $\left(M_{\mathrm{r}} 50,000\right.$ and 5000$)$ held together by a disulphide bridge, has no detectable protease-inhibiting activity (Rjörk \& Fish, 1982 ).

Antithrombin III is a member of the serpin superfamily (Carrell \& Boswell, 1986), which includes inhibitors of serine proteases as well as ovalbumin (Hunt \& Dayhoff, 1980) of no known anti-protease activity. Sequence alignments within this family led to the hypothesis that these proteins have evolved from an ancestral serine proteinase inhibitor. The N-terminal parts of these proteins show significant variation in length. In the case of human antithrombin III, it has been shown that Pro41 (Chang \& Tran, 1986), Arg47 (Koide et al., 1984), Trp49 (Blackburn et al., 1984) and Lys 125 (Peterson et al., 1987) are essential for heparin binding and activation of the inhibitor. A contrario, the antithrombin III molecule deprived of its carbohydrate at Asn 135 was shown to display a higher affinity to heparin (Brennan et al., 1987).

The X-ray structure analysis of ATIII was undertaken in order to provide a molecular description of

†Abbreviations used: ATIII, bovine antithrombin III; $\mathrm{AT}_{\mathrm{M}}$, cleaved antithrombin. the heparin and thrombin binding sites. From a topological view point, it will also be interesting to compare the antithrombin III structure with that of the cleaved and homologous $\alpha-1$ antitrypsin molecule (Loebermann et al., 1984).

Antithrombin III was purified from bovine plasma by affinity chromatography on heparinSepharose. The protein displayed normal activity against thrombin. Crystals were obtained by the microdialysis method (Zeppezauer et al. 1968) at $4^{\circ} \mathrm{C}$. A solution of protein $(13 \mathrm{mg} / \mathrm{ml})$ in 80 mм-phosphate buffer ( $\mathrm{pH} \mathrm{6.2)}$ was equilibrated by batch dialysis against the same buffer containing $1 \mathrm{~mm}$-cadmium chloride and ammonium sulphate at $20 \%$ saturation. The protein solution was limpid, although the dialysis medium displayed some tur bidity, indicating possible cadmium uptake by the protein. The protein solution was then microdialysed against the same medium containing $50 \%$ saturated ammonium sulphate. After one week, the ammonium sulphate concentration was increased to $70 \%$ saturation. Crystals appeared within three weeks as cubes of $0.3 \mathrm{~mm} \times 0.3 \mathrm{~mm} \times 0.3 \mathrm{~mm}$. Crystals were also grown in the presence of mercuric or zinc divalent ions in order to derive phase information if the cations proved to be located at specific binding positions.

The crystals were analysed using $\mathrm{X}$-ray synchrotron sources at LURE (Orsay, France) and CHFSS (Cornell University, Ithaca, NY, U.S.A.). Symmetry of the diffraction patterns and the specific extinction coefficients are consistent with the tetragonal space groups $P 4_{3} 2_{1} 2$ or $P 4_{1} 2_{1} 2$. The cell parameters are: $a=b=91.4 \AA, \quad c=3831 \AA$ ( $1 \AA=0 \cdot 1 \mathrm{~nm}$ ). The asymmetric unit contains two molecules of ATIII which give a erystal volume per unit of molecular weight of $3 \cdot 6 \AA^{3} /$ dalton and a $V / Z$ value of $2 \times 10^{5} \mathrm{~A}^{3}$, close to that found for $\alpha-1$ anti-trypsin (Loebermann et al., 1984). This value is in agreement with the molecular replacement analysis. Crystals are very stable under $\mathrm{X}$-ray exposure and up to $20^{\circ}$ oscillation could be collected on the same crystal. The diffraction limit is $3 \cdot 0 \AA$. Complete data sets to $3.5 \AA$ were collected for crystals grown in the presence of $\mathrm{CdCl}_{2}, \mathrm{HgCl}_{2}$ or 
$\mathrm{ZnCl}_{2}$ and $70 \%$ of the complete data set to $3.0 \mathrm{~A}$ are available. High-resolution data collection is underway. One heavy-atom derivative was prepared by soaking native crystals in a $2 \mathrm{~mm}$ solution of $\mathrm{PtCl}_{4}$ for three days. This derivative was isomorphous to the native data to $5 \AA$ resolution. Native crystals were soaked with a solution of the pentasaccharide molecule (Choay et al., 1983), which represents the shortest heparin fragment active with respect to inhibition of factor $\mathrm{Xa}$. The corres ponding diffraction data $(80 \%$ complete at $3.5 \AA$ resolution) are isomorphous to the native data to $4 \cdot 0 \AA$ resolution.

Biochemical analyses were performed in order to check the molecular species present in the crystals. These were washed twice in concentrated ammonium sulphate, and after careful drying, dissolved in water. SDS/polyacrylamide gel electrophoresis under reducing conditions revealed a major band corresponding to $\mathrm{AT}_{\mathrm{M}}$. Control of supernatant mother liquor showed two bands: the major one corresponded to native ATIII, the second band to $\mathrm{AT}_{\mathrm{M}}$ of smaller molecular weight. While the biological activity of the protein in the mother liquor was still measurable, there was no detectable activity in redissolved crystals. Moreover, amino acid analysis of the $\mathrm{N}$-terminal part indicated the presence of two $\mathrm{N}$ termini: one corresponds to the known sequence of the bovine protein (Kurachi et al., 1976) and the second begins at Leu395 (human ATIII numbering), one amino acid away from the cleavage site. Their respective amounts agree, within the limits of error, to the expected ratio of $\mathrm{N}$-termini species. It seems that $\mathrm{AT}_{\mathrm{M}}$ fractionates itself out of the solution by crystallizing preferentially. The fact that the mother liquor still displays activity is not in favour of a continuous breakdown during crystallization. This residual activity cannot be easily quantified due to the presence of cadmium ions used for the crystallization of the protein which were shown to affect antithrombin III activity in fresh preparations. It should also be mentioned that crystallization of antithrombin III is dependent upon protein batches. One reason might be the microheterogeneity brought about by the four oligosaccharide chains, which is clearly seen on isoelectrofocusing gel analysis. The variability in crystallization behaviour mav be related to this heterogeneity if some of the oligosaccharide chains are involved in the crystal packing of the molecules. Several crystallization experiments using modified antithrombin III species are currently underway.

Structure determination of antithrombin III is currently being pursued using the isomorphous replacement method and the molecular replacement techniques with $\alpha-1$ antitrypsin tridimensional structure $(30 \%$ sequence homology with the human protein) as a model. A clear signal in the cross rotation function is consistent with two molecules of antithrombin III per asymmetric unit. This might reflect conservation of the core in the three-dimensional structure of these two members of the serpin family.
From a functional viewpoint, there is still a major interest in the structure determination of antithrombin III, particularly the description of the heparin binding site, which seems very similar within antithrombin III of different origins (Gettins, 1987) and homologous to the one of the histidine rich glyeoprotein (Koide et al., 1986).

We thank Dr Petitou and Lormeau (Institut (hoay) for stimulating discussions. Mr Maman and Dr Piemont (Faculté de Médecine, Strasbourg) for biochemical analysis, Dr Reinbold and Dr Mejdoub (IBMC, Strasbourg) for amino acid sequencing and the staff from the glassware workshop at the Institut de Chimie in Strasbourg for facilities placed at our disposal. We also thank the stalls of LURE (Orsay, France) and CHESS (Ithaca, U.S.A.) for excellent data collection facilities.

\section{J. P. Samama \\ M. Delarue ${ }^{1}$ \\ L. Mourey ${ }^{1}$ \\ J. Choay ${ }^{2}$ \\ D. Moras ${ }^{1}$}

${ }^{1}$ Laboratoire de Cristallographie Biologique, I.B.M.C. du C.N.R.S.

15 rue René Deseartes, 67000 Strasbourg, France

${ }^{2}$ Institut Choay, 46 Av. Théophile Gautier

75782 Paris Cedex France

Received 10 July 1989 . and in revised form 7 August 1989.

\section{References}

Björk, I. \& Fish, W. W. (1982). J. Biol. Chem. 257. 9487-9493.

Blackburn, M. N., Smith, R. L., Carson, J. \& Sibley, ( ( (1984). J. Biol. Chem. 259, 939941

Brennan, S. O., George, P. M. \& Jordan. R. E. (1987). FEBS Letters, 219, 431-436.

Carrell, R. W. \& Boswell, D. R. (1986). In Proteinase Inhibitors (Barrett \& Salvesen, eds). pp. 403-420. Elsevier Science Publishers BV, Amsterdam.

Chang, J.-Y. \& Tran, T. H. (1986). J. Biol. Chem. 261 , $1174-1176$.

Choay, J., Petitou, M., Lormeau, J. C., Sinay, P., Casu. B. \& Gatti, G. (1983). Biochem. Biophys. Res. Commun. 116, $492-499$

Damus, P. S., Hicks, M. \& Rosenberg, R. D. (1973). Nature (London), 246, 355-357.

Gettins, P. (1987). Biochemistry, 26, 1391-1398

Hoylaerts, M., Owen, W. G. \& Collen. D. (1984). J. Biol. Chem. 259. 5670-5677

Hunt, L. T. \& Dayhoff, M. O. (1980). Biochem. Biophys Res. Commun. 95, 864-871.

Jordan, R. E., Oosta, G. M., Gardner, W. T. \& Rosenberg. R. D. (1980). J. Biol. Chem. 255, 10081-10090

Jörnvall, H., Fish, W. W. \& Björk, I. (1979). FEBS Letters, 106, 358-362.

Koide, T., Odani, S., Takahashi, K., Ono, T. \& Sakuragawa, N. (1984). Proc. Nat. Acad. Sci., U.S.A 81. 289-293

Koide, T., Foster, D. \& Odani, S. (1986). FEBS Letters. 194, 242-244. 
Kurachi, K., Schmer, G., Hermodson, M. A. Teller, D. C. \& Davie, E. W. (1976). Biochemistry, 15, 368-372.

Loebermann, H., Tokuoka, R., Diesenhofer, J. \& Hubert, R. (1984). J. Mol. Biol. 177, 531-556

Peterson, C. B., Noyes, C. M., Pecon, J. M., Church, F. C. \& Blackburn. M. N. (1987). J. Biol. Chem. 262 , $8061-8065$.
Rosenberg, R. D. (1977). Fed. Proc. Fed. Amer. Soc. Exp. Biol. 36, 10-18.

Travis, J. \& Salvensen, G. S. (1983). Annu. Rev. Biochem. 52, 655-709.

Zeppezauer, M., Eklund, H. \& Zeppezauer, E. S. (1968). Arch. Biochem. Biophys. 126, 564.

Edited by R. Huber 